\title{
MAPPING COMPETENCIES: IDENTIFYING GAPS IN MANAGERIAL NURSING TRAINING
}

\author{
Aida Maris Peres ${ }^{1}$, Tessy Nnonyelum Miozzo Ezeagu², Priscila Meyenberg Cunha Sade ${ }^{3}$, \\ Pollyana Bahls de Souza ${ }^{4}$, Danelia Gómez-Torres ${ }^{5}$
}

${ }^{1}$ Ph.D. in Nursing. Professor, Nursing Department, Universidade Federal do Paraná (UFPR). Curitiba, Paraná, Brazil. E-mail: aidamaris. peres@gmail.com

${ }^{2}$ Nursing Graduate Student, UFPR. Scholarship, Fundação Araucária. Curitiba, Paraná, Brazil. E-mail: tmiozeagu@yahoo.com.br

${ }^{3}$ Doctoral. student, Post-graduate Program in Nursing, UFPR. Professor, Department of Nursing, UFPR. Capes Research Grant. Curitiba, Paraná, Brazil. E-mail: priscila.sade@gmail.com

${ }^{4}$ M.Sc. Professor, Universidade Estadual do Centro Oeste do Paraná. Garapuava, Paraná, Brazil. E-mail: pobahls@gmail.com

${ }^{5}$ Ph.D. in Nursing. Professor, Universidad Autónoma del Estado de México. Toluca, Estado del Mexico, Mexico. E-mail: gomezdanelia@ usa.net

\section{ABSTRACT}

Objective: mapping necessary competencies in managerial nursing training.

Method: a cross-sectional study conducted between March and June 2013 with 258 students from three Higher Education Institutions of a municipality in the South of Brazil.

Results: mapping made it possible to identify necessary competencies for managerial nursing training, including those acquired and gaps. The relative majority of the students considered having the right attitude to act as a nurse in the managerial dimension; however, significant gaps during their training were identified in managerial competencies of supervision, auditing and change processes.

Conclusion: this mapping provides subsidies for pedagogical planning, seeking to promote the acquisition of managerial competencies during undergraduate course training.

DESCRIPTORS: Professional competence. Nursing students. Competency-based education. Research in nursing education. Research in nursing administration.

\section{MAPEAMENTO DE COMPETÊNCIAS: GAPS IDENTIFICADOS NA FORMAÇÃO GERENCIAL DO ENFERMEIRO}

\section{RESUMO}

Objetivo: mapear as competências necessárias para a formação gerencial do enfermeiro.

Método: estudo de corte transversal realizado entre março e junho de 2013 com 258 discentes de três Instituições de Ensino Superior de um município do Sul do Brasil.

Resultados: o mapeamento possibilitou a identificação das competências gerenciais necessárias à formação, as adquiridas e as lacunas. A maioria relativa dos discentes considerou ter atitude para atuar como enfermeiro na dimensão gerencial, entretanto, para as competências gerenciais de supervisão, auditoria e processos de mudança, identificaram-se gaps significativos durante sua formação.

Conclusão: este mapeamento fornece subsídios ao planejamento pedagógico, com vistas a promover a apreensão de competências gerenciais durante a graduação.

DESCRITORES: Competência profissional. Estudantes de enfermagem. Educação baseada em competências. Pesquisa em educação de enfermagem. Pesquisa em administração de enfermagem. 


\section{MAPEAMIENTO DE COMPETENCIAS: GAPS IDENTIFICADAS EN LA FORMACIÓN GERENCIAL DEL ENFERMERO}

\section{RESUMEN}

Objetivo: mapear las competencias necesarias para la formación gerencial de las enfermeras.

Método: estudio transversal realizado entre marzo y junio de 2013, con 258 estudiantes de tres centros de enseñanza superior de una ciudad en el sur de Brasil.

Resultados: el mapeo permitió la identificación de las competencias gerenciales necesarias para la formación, las adquiridas y los vacíos. La mayoría relativa de los estudiantes considera que poseen la actitud para actuar como enfermeros en la dimensión de gestión, sin embargo, para la gestión de los procesos de supervisión, auditoría y de cambio, identifican algunas lagunas importantes en su educación.

Conclusión: este mapeo proporciona subsidios para la planificación educativa, con el fin de promover la detención de las capacidades de gestión durante el grado.

DESCRIPTORES: Competencia profesional. Estudiantes de enfermería. Educación basada en las competencias. Investigación en la educación de enfermería. Investigación en la administración de enfermería.

\section{INTRODUCTION}

Despite being incorporated by the working world, the concept of competence was introduced in training proposals and professional updates. In this logic, competence relates to a combination of its three fields - Knowledge, Skill and Attitude, acquired during educational processes and expressed by the individual through their behavior in a particular professional context. ${ }^{1-2}$

Knowledge is attributed as the denotative of knowing, and corresponds to information acquired by individuals to an ability, meaning the know-how; which is related to one's ability to put into practice acquired knowledge; and the attitude, whose denotative is knowing how to be/to act, related to the individual's behavior in a professional context. ${ }^{2}$

On the world scene, some studies on professional training point out that the construction of competencies implies articulating different knowledge for developing professional practice, not only in acquiring and incorporating knowledge and skills, but also in personal and relational attitudes which aim at constructing a common project in order to transform the health reality. ${ }^{3-5}$ In Brazil, the relevance of this theme has advanced to legal determinations for nursing education in the country, with the elaboration of the National Curricular Guidelines (DCNs) from 2001, which emphasized Nursing training based on developing competencies, including those related to administration/management. ${ }^{2,6}$

Development of management skills/competencies is an indispensable set of knowledge identified in order to plan, make decisions, interact and manage people. Therefore, establishing the competencies to be developed during nurses' training is still a challenge. ${ }^{3,7}$ The discrepancy between the required skills and those existing in an organization stand out. Institutional demands in health require professionals with increasingly complex training. However, even though the debate is scarce, it is known that there are gaps between the teaching-learning process and the work environment regarding the acquired skills for future nursing professionals. ${ }^{2,7}$

Mapping competencies is a managerial tool that allows for diagnosing discrepancies between the competencies necessary to fulfill organizational requirements and the existing internal competencies. ${ }^{8}$ In the case of this study of innovative application in the educational scenario, these discrepancies are represented by revealing gaps in developing the skills required in training nurses, with the purpose of supporting the planning and evaluation of pedagogical projects in undergraduate nursing courses.

In view of the above, issues related to the development of competencies must be problematized by educational institutions in order to prioritize what is fundamental for Nursing training and their future action in the work environment. The present study aims to map the competencies necessary for training managerial nurses.

\section{METHOD}

This is a cross-sectional study using the competency mapping method, ${ }^{8}$ conducted between March and June 2013 in three undergraduate nursing courses located in a municipality in the South of Brazil.

This mapping followed three steps: 1) identifying managerial competencies necessary for training nurses through documentary analysis, between January and March of 2013, with its sources being the 27 syllabus/program topics and 58 objectives of the Nursing Administration discipline included in the pedagogical projects in force in the year 2013 of the three higher education institutions (HEIs); 2) application of a questionnaire between March and April 2013, with students participating in the study 
pointing out the managerial knowledge, skills and attitudes acquired during the training; 3 ) identifying the gaps between the competencies described by the educational institution in the documentary analysis and the competencies acquired by the students according to their answers in the questionnaires; this stage was carried out from April to June 2013.

A known population of 359 students from the three mapped undergraduate courses was considered to determine the number of participants in the study. A confidence level of $99 \%$ and a permissible margin of error of $4.3 \%$ were established for sample calculation, obtaining an intentional sample of 258 students. ${ }^{9}$

Inclusion criteria for the participants of the research were established according to the following points: being regularly enrolled in one of the nursing courses in one of the three educational institutions and attending the second year of the nursing course. As exclusion criteria, the following principles were defined: students enrolled in the first year of the nursing course, or those who were not present on the dates and times scheduled with the institutions for the questionnaire application.

In order to organize the data collected in the first stage, a structured script was used that allowed for analyzing the disciplines' syllabi/programs and objectives, based on the competencies described in the DCNs for undergraduate nursing courses. In the second stage, a questionnaire composed of two semistructured and 17 structured questions was applied to second to fifth year students, with the purpose of obtaining conceptions from the participants related to managerial competencies acquired throughout their undergraduation, as it is from the second year that they begin to have contact with content related to Nursing administration in the studied HEIs.

In order to define the competency gaps, a classification was implemented based on the percentage of the students who answered that they did not gain/achieve the knowledge, skills and/or attitudes proposed in the Nursing Administration discipline by following the indicators adopted in the methodological framework, which consist in identifying gaps between the necessary skills and those actually achieved. ${ }^{8}$ Therefore, it was agreed that competency gaps would be classified as the difference between the percentages of the necessary competencies identified from the documentary research and those acquired as pointed out in the questionnaires by the students who obtained a score greater than $1 \%$; and those with a score greater than or equal to $50 \%$ as significant competency gaps. This score corresponds to the value of $50 \%$, assigned as the average minimum final score for approval in the Nursing Administration discipline in these HEIs.

Data analysis of the documents allowed for identifying the competencies and their fields according to the classification into Knowledge, Skills and Attitudes (KSA). Data analysis of the questionnaires was performed by simple descriptive statistics (absolute and relative frequencies), using the statistical functions of the Biostat 2007 software.

Data collection began after project approval by the Research Ethics Committee involving $\mathrm{Hu}$ man Subjects of a university in the South of Brazil. Permission was granted on March 27, 2013, under opinion number 231.163, and Certificate of Presentation for Ethical Appreciation (CAAE) 098448113.5.0000.0102, as well as after the participants signed the Clear and Informed Consent Form.

\section{RESULTS}

Specific competencies identified through documentary analysis were classified into the three KSA fields. The KSAs required for general nursing training are shown in the pedagogical projects of the analyzed HEIs and in the National Curricular Guidelines (DCNs) for undergraduate nursing courses. Each document showed a group of specific competencies in the syllabus/programs and objectives of the Nursing Administration discipline. Not all of the specific competencies found were identified in the three KSA fields (Chart 1).

\section{Chart 1 - Synthesis of skills and fields identified from the Nursing Administration discipline's syllabus/ program topics and objectives. South of Brazil, 2013}

\begin{tabular}{|l|c|c|c|}
\hline \multirow{2}{*}{ Specific competencies } & \multicolumn{3}{|c|}{ Competence teaching field } \\
\cline { 2 - 4 } & Knowledge & Skills & Attitudes \\
\hline Planning in health/nursing & Present & Present & Present \\
\hline Information system & Present & Present & Absent \\
\hline Human, physical and material resources & Present & Present & Present \\
\hline
\end{tabular}




\begin{tabular}{|l|c|c|c|}
\hline \multirow{2}{*}{ Specific competencies } & \multicolumn{3}{|c|}{ Competence teaching field } \\
\cline { 2 - 4 } & Knowledge & Skills & Attitudes \\
\hline Process of change & Present & Absent & Absent \\
\hline Time management & Present & Present & Absent \\
\hline Leadership & Present & Present & Present \\
\hline Decision Making & Present & Present & Present \\
\hline Teamwork & Present & Present & Present \\
\hline Supervision & Present & Present & Present \\
\hline Conflict resolution & Present & Present & Present \\
\hline Audit & Present & Absent & Present \\
\hline Communication & Present & Present & Absent \\
\hline Continuing/Permanent education & Present & Present & Absent \\
\hline
\end{tabular}

In the second stage, from the 258 questionnaires analyzed, $80(31 \%)$ students were enrolled in the $2^{\text {nd }}$ year, $93(36 \%)$ in the $3^{\text {rd }}$ year of the course, $59(23 \%)$ in the $4^{\text {th }}$ year and $26(10 \%)$ were in their $5^{\text {th }}$ year. Regarding the Nursing Administration discipline, we verified that $78(30 \%)$ students had already taken it, which suggests that they had already experienced some of the skills listed in the applied questionnaire.

Regarding the competencies selected in the questionnaire to act as a nurse in the management area according to the KSA classification: 124 (48\%) of the students reported having learned Knowledge, 110 (42.6\%) Skills, and 158 (61.4\%) Attitudes throughout the undergraduate nursing course. However, there was an increase in the percentage among students after they finished the discipline Nursing Administration, up to 199 (77\%), 142 (55\%), and 219 (85\%), respectively.

In general, the answers obtained regarding the specific competencies mentioned by the students were those more taught in theoretical classes than in practical classes or in the curricular internship (Table 1).

Table 1 - Absolute and relative frequency of managerial competencies addressed during nursing graduation of three Higher Education Institutions. Southern Brazil, 2013

\begin{tabular}{lrrrrrrr}
\hline \multirow{2}{*}{ Specific competence } & \multicolumn{3}{c}{$\begin{array}{c}\text { Theoretical } \\
\text { classes }\end{array}$} & \multicolumn{2}{c}{$\begin{array}{c}\text { Practical } \\
\text { classes }\end{array}$} & \multicolumn{3}{c}{$\begin{array}{c}\text { Curricular } \\
\text { internship }\end{array}$} \\
& n & \multicolumn{1}{c}{$\%$} & n & \% & n & $\%$ \\
\hline Teamwork & 216 & 83.7 & 179 & 69.4 & 136 & 52.7 \\
Communication & 198 & 76.7 & 168 & 65.1 & 124 & 48.1 \\
Decision Making & 173 & 67 & 149 & 57.7 & 131 & 50.8 \\
Planning in health/nursing & 166 & 64.3 & 126 & 48.8 & 96 & 37.2 \\
Leadership & 159 & 61.6 & 113 & 43.8 & 86 & 33.3 \\
Continuing/Permanent education & 151 & 58.5 & 107 & 41.5 & 82 & 31.8 \\
Time management & 146 & 56.6 & 155 & 60.1 & 104 & 40.3 \\
Conflict resolution & 139 & 53.9 & 114 & 44.2 & 83 & 32.2 \\
Information system & 122 & 47.3 & 86 & 33.3 & 70 & 27.1 \\
Human/physical and material resources & 112 & 43.4 & 83 & 32.2 & 65 & 25.2 \\
Process of change & 108 & 41.9 & 75 & 29 & 64 & 24.8 \\
Supervision & 74 & 28.7 & 46 & 17.8 & 43 & 16.6 \\
Audit & 55 & 21.3 & 29 & 11.2 & 30 & 11.6 \\
\hline
\end{tabular}


Table 2 reveals the gaps between the KSA fields of specific competencies identified by documentary research and the competences achieved by the students, according to data from the questionnaire.

Table 2 - Knowledge, Skill and Attitude gaps found, Southern Brazil, 2013

\begin{tabular}{|c|c|c|}
\hline \multicolumn{3}{|c|}{ Knowledge } \\
\hline Specific competence & GAP (\%) & Competency achieved (\%) \\
\hline Communication $\ddagger$ & 1 & 99 \\
\hline Leadership § & 3 & 97 \\
\hline Teamwork $\S$ & 3 & 97 \\
\hline Decision Making † & 7 & 93 \\
\hline Planning in health / nursing § & 9 & 91 \\
\hline Information system $\S$ & 10 & 90 \\
\hline Conflict resolution $\S$ & 10 & 90 \\
\hline Time management $\S$ & 17 & 83 \\
\hline Continuing / Permanent education $\S$ & 17 & 83 \\
\hline Process of change $\S$ & 21 & 79 \\
\hline Human, physical and material resources $\S$ & 24 & 76 \\
\hline Supervision $\S$ & 28 & 72 \\
\hline Audit $\S$ & 41 & 59 \\
\hline \multicolumn{3}{|c|}{ Skills* } \\
\hline $\begin{array}{r}\text { Specific competence } \\
\end{array}$ & GAP (\%) & Competency achieved (\%) \\
\hline Conflict resolution $\S$ & 30 & 70 \\
\hline Teamwork $\S$ & 35 & 65 \\
\hline Communication $\S$ & 37 & 63 \\
\hline Decision Making § & 37 & 63 \\
\hline Time management $\S$ & 39 & 61 \\
\hline Continuing / Permanent education $\S$ & 40 & 60 \\
\hline Planning in health / nursing § & 41 & 59 \\
\hline Leadership $\S$ & 45 & 55 \\
\hline Information system $\S$ & 48 & 52 \\
\hline Human, physical and material resources $\S$ & 49 & 51 \\
\hline Supervision || & 56 & 44 \\
\hline \multicolumn{3}{|c|}{ Attitudes $\uparrow$} \\
\hline Specific competence & GAP (\%) & Competency achieved (\%) \\
\hline Teamwork $\S$ & 21 & 79 \\
\hline Conflict resolution $\S$ & 23 & 77 \\
\hline Decision Making $\S$ & 27 & 73 \\
\hline Planning in health / nursing § & 33 & 67 \\
\hline Leadership $\S$ & 41 & 59 \\
\hline Human, physical and material resources $\S$ & 44 & 56 \\
\hline Process of change || & 51 & 49 \\
\hline Supervision || & 55 & 45 \\
\hline Audit || & 65 & 35 \\
\hline
\end{tabular}

* No mention of specific managerial skills were found for Auditing or Process of change in the approach of skills in the documentary analysis; $\uparrow$ No mention of specific managerial competencies were found for Time management, Communication, Information system or Continuing/permanent education in the approach of attitudes in the documentary analysis; ‡ Competitions found without a gap; § Skills found with a gap; | | Competencies found with a significant gap. 


\section{DISCUSSION}

The syllabus/program topics and objectives of the Nursing administration disciplines revealed a group of specific competencies in agreement with the DCNs guidelines. However, not all data were listed in the three KSA fields when the documents were analyzed in the first research stage. Skills and Attitude were not present in more than half of the specific competencies.

It should be noted that after the curricular changes that took place in Brazil from the creation of the DCNs for nursing undergraduate courses, the development of competencies must also be conducted and directed towards acquiring and developing skills and attitudes. ${ }^{2}$ Thus, teaching content aimed at developing the necessary competencies for nursing work need to be supported by knowledge regarding products, services and care needs; skills for when they are performing the work or analyzing patients' expectations; and with favorable attitudes towards the legal and ethical principles of work..$^{5,10-11}$

In general, both before and after taking the Nursing Administration discipline, the majority of the students admitted having more acquired the area of Attitudes in order to act in the managerial dimension. On the other hand, they revealed that the specific competencies were more approached in the theoretical classes than in practical classes or in the internship. Therefore, we can infer that these competencies were more related to Knowledge than to Skills or Attitudes.

A study carried out with 59 graduates of a nursing course pointed out that specific competencies had more emphasis on Knowledge and Skills than on Attitudes throughout the course, revealing that the attitudinal field is the one with the greatest gap during undergraduation, and that Attitudes end up being developed in professional practice. ${ }^{12}$

According to students' perception, the only specific competence that was more addressed during practical than theoretical classes was time management. This result can be explained by the practical nature required in the field of Skills for developing this competence, which are acquired during organizational and planning activities required for practical classes and internships. This competence is a decisive factor in organizing nursing work, since it facilitates acquiring the perception of time; making optimal use of available time to plan and develop health work processes. ${ }^{13}$

Gaps have been observed in all managerial competencies among all three KSA fields. Despite these gaps being less than $50 \%$, they require atten- tion from HEIs and teachers, especially those that are close to this percentage such as what is observed for the Skills field with the following competencies: Leadership; Information systems; Human, physical and material resources.

Among the managerial competencies, we can deduce that leadership is the most required for exercising nursing work processes. It is intrinsic that nurses assume the role of being a leader as soon as they graduate. ${ }^{7,14-15}$ On the other hand, information systems comprise the routine work of nurses, presently considered as indispensable for their activity since they are aimed at gaining time in accessing information, which facilitates thinking; in operational support, which facilitates doing; in managing people, which assists in the decision-making process and motivates communication among the teams. ${ }^{6,16} \mathrm{Re}-$ garding the human, physical and material resources competence, this should be used as a plan that foresees short, medium and long term organizational demands with the purpose of obtaining quality, efficacy and efficiency in the health work process. ${ }^{17}$

Among the significant gaps above $50 \%$ in the mapping of specific competencies, we can highlight Supervision in the fields Skills and Attitudes, and the Process of Change and Auditing, both in the Attitudes field. Auditing was not mentioned in the Skills field.

The Skills and Attitudes addressed in Supervision which resulted in a significant gap in this study are basic to nursing training, since in addition to the leadership competence, they are required by the Law of professional nursing exercise and by the Nursing Code of Ethics. Nurses performance in supervising the work of the nursing team happens through operative instruments used with the intention of optimizing actions of the groups in their work environment, and requires Skills and Attitudes to attain resolution with the institutional resources that are offered to them. ${ }^{18-20}$

We highlight the importance of trained professionals in addressing and solving interpersonal, intergroup and institutional problems related to mobilizing the competence processes of change. Nurses need to seek cognitive and technical competencies, but also Behavioral and Attitude skills to innovate and sustain the transformations required in their managerial work in health. The Attitude field has proved to be challenging during academic training, and consequently in professional practice, given that the Process of Change competence in the current conjuncture is directly linked to intense and rapid transformations, such that nurses must recognize and be able to express this dynamism in a critical and reflexive manner, sensitizing/encourag- 
ing their team towards adherence to the necessary organizational changes.,12

Also in the Attitudes field, the gap related to Auditing reveals that students did not recognize this competence, which is used for systematic and formal evaluation of an activity by someone not directly involved in its execution, to determine whether this activity is being carried out in accordance with its objectives. When performing their duties, nurses use nursing audits to verify whether the quality of care is adequate, as this competence supports care management and decision making. ${ }^{21-23}$

The discussion of the results suggests that managerial training of future nurses should be reviewed in order to mobilize competencies from significant experiences to be reflected in professional practice, especially in the Skills and Attitudes fields. These academic experiences need to be supported by opportunities that enable efficient processes for decision making and communication, that motivate autonomy, co-responsibility and teamwork. ${ }^{20,24}$

As limitations, we can point out the need to better understand the HEIs participating in the study, since their specificities, characteristics and organization culture need to be considered in order to obtain an accurate diagnosis of the local situation. This situational recognition is also necessary in planning the teaching-learning process, so that it can be meaningful, consistent and able to mobilize nursing students to seek new knowledge in a contextualized perspective, aiming for competent professional performance.

\section{CONCLUSION}

We highlight that it was possible to achieve the study objective of mapping the necessary competencies for managerial training of nurses. This mapping made it possible to more clearly diagnose how the teaching-learning process is consolidated in the approach of managerial subjects relevant to the nursing undergraduate course program/syllabus. The greatest number of specific managerial skills and the smallest gaps were verified in the Knowledge field. The largest gaps were concentrated in the other two fields, which suggests that Skills and Attitudes are less acquired by the students in Nursing Administration disciplines.

In view of the above, it can be inferred that there is a need for changes in managerial nursing training. To that end, HEIs and teachers need to rethink their work in a critical-reflective way. It is necessary to overcome resistance to change, to invest in spaces of practice and in teacher training. The teaching-learning process in these disciplines needs to occur through method and planning, with both being in tune with theory, practice and internships, comprising real work situations that allow learning to be mediated and interpreted according to the work context.

In this sense, we propose a continuity of further studies that map competencies in the area of nursing education, considering that this type of research is still scarce. We conclude that the use of this method is valid for modifying and updating the didactic-pedagogical approach of Nursing Management disciplines taught by HEIs, reducing the gaps between teaching the planning and learning of management skills in the undergraduation context.

\section{REFERENCES}

1. Serrano MTP, Costa ASMC, Costa NMVN. Cuidar em enfermagem: como desenvolver a(s) competência(s). Rev Enf Ref [Internet]. 2011 Mar [cited 2015 Jul 08]; serIII(3):15-23. Available from: http://www.scielo. mec.pt $/$ scielo.php?script $=$ sci_arttext\&pid $=$ S087402832011000100002\&lng=es

2. Almeida ML, Peres AM. Conocimientos, habilidades y actitudes sobre la gestión de los egresados de enfermería de una universidad pública brasileña. Invest Educ Enferm [Internet]. 2012 Jan-Abr [cited 2015 Jul 8]; 30(1):66-76 Available from: http:/ / www.scielo. org.co/scielo.php?script $=$ sci_arttext\&pid $=$ S012053072012000100008\&lng $=$ en\&nrm $=$ iso

3. CameloSHH, Angerami ELS. Professional competence: the construction of concepts, strategies developed by health services and implications for nursing. Texto Contexto Enferm [Internet]. 2013 Jun [cited 2015 Jul 08]; 22(2):552-60. Available from: http://dx.doi. org/10.1590/S0104-07072013000200034

4. Soto-Fuentes P, Reynaldos-Grandón K, MartínezSantana D, Jerez-Yáñez O. Competencias para la enfermera/o en el ámbito de gestión y administración: desafíos actuales de la profesión. Aquichán [Internet]. 2014 Mar [cited 2015 Jun. 15]; 14(1):79-99. Available from: http://www.scielo.org.co/pdf/aqui/v14n1/ v14n1a08.pdf

5. Blažun H, Kokol P, Vošner J. Survey on specific nursing competences: students' perceptions.Nurse Educ Prac. [Internet]. 2015 Feb [cited 2016 Mai 09]; 15(5):359-65. Available from: http://www.sciencedirect.com/ science/article/pii/S1471595315000293

6. Peres AM, Ciampone MHT. Gerência e competências gerais do enfermeiro. Texto Contexto Enferm. [Internet]. 2006 Sep [cited 2015 Oct 29]; 15(3):492-9. Available from: http://dx.doi.org/10.1590/S010407072006000300015

7. Sade PMC, Peres AM. Development of nursing management competencies: guidelines for continuous education services. Rev Esc Enferm USP 
[Internet]. 2015 Dec [cited 2016 Apr 25]; 49(6):988-94. Available from: http://dx.doi.org/10.1590/S0080623420150000600016

8. Brandão HP. Mapeamento de competências: métodos, técnicas e aplicações em gestão de pessoas. São Paulo (SP) Atlas; 2012.

9. Agranonik M, Hirakata VN. Cálculo de tamanho de amostras: proporções. Rev HCPA [Internet]. 2011 [cited 2016 Ago 17]; 33(1):382-8. Available from: http://www.seer.ufrgs.br/hcpa/article/ viewFile/23574/15837

10. Siles J, Solano-Ruiz MC, Freitas GF, Oguisso T. Political systems and the perspective on nursing education during the Spanish transition (from the Franco Regime to Democracy). A Contribution based on nursing history. Aquichán [Internet]. 2010 Dec [cited 2015 Jul 8]; 10(3):192-203. Available from: http:/ / www.redalyc.org/articulo.oa?id=74116984002

11. Latrach-Ammar C, Febré N, Demande I, Araneda J, González I. La importancia de las competências em la formación de enfermeria. Aquichán [Internet]. 2011 Dec [cited 2015 July 08]; 11(3):305-15. Available from: http:/ / www.scielo.org.co/scielo.php?script=sci arttext\&pid=S1657-59972011000300006\&lng=en

12. Almeida MDLD, Peres AM, Bernardino E, Santos MF. Egressos de uma universidade pública e perspectivas de atuação no gerenciamento em enfermagem. Rev Rene [Internet]. 2014 Nov/Dec [cited 2015 Jul 8]; 15(6):933-41. Available from: http://www. revistarene.ufc.br/revista/index.php/revista/ article/view/1806/pdf

13. Montezeli JM, Peres AM, Bernardino E. Nurse management skills required at an emergency care unit. J Res Fundam Care [Internet] 2013 Jul-Set [cited 2015 Jul 8]; 5(3):245-52. Available from: http:/ / dx.doi. org/10.9789/2175-5361.2013.v5i3.245-252

14. Amestoy SC, Backes MS, Triandade LL, Canever BP. The scientific production regarding leadership in the context of nursing. Rev Esc Enferm USP [Internet]. 2012 Feb [cited 2014 Nov 20]; 46(10):219-24. Available from: http://www.scielo.br/pdf/reeusp/v46n1/ en_v46n1a30.pdf

15. Ekström L, Idvall E. Being a team leader: newly registered nurses relate their experiences. J Nurs Manag. [Internet]. 2015 Jul [cited 2015 Dec 25]; 23(1):75-86. Available from: http://onlinelibrary. wiley.com/doi/10.1111/jonm.12085/full

16. Gonçalves LS, Castro TC, Fialek SN. Computer experience of Brazilian nurses of a teaching hospital. J Health Inform. [Internet] 2015 Jul-Set [cited 2015
Nov 30]; 7(3):82-7. Available from: http://www.jhisbis.saude.ws/ojs-jhi/index.php/jhi-sbis/article/ view/342/237

17. Baldissera VDA, Góes HLF. El método Altadir de planificación popular como instrumento de enseñanza de la gestión en enfermería. Invest Educ Enferm.[Internet]. 2012 Jul-Dec [cited 2015 Jul 8]; 30(2):252-9. Available from: http://www.scielo. org.co/scielo.php?script $=$ sci_arttext\&pid $=$ S012053072012000200011\&lng=pt\&tlng=pt

18. Lelli LB, Bernardino E, Peres AM, Fabriz LA. Estratégias gerenciais para o desenvolvimento de competências em enfermagem em hospital de ensino. Cogitare Enferm [Internet]. 2012 Abr-Jun [cited 2015 out 29]; 17(2):262-9. Available from: http:// ojs.c3sl.ufpr.br/ojs/index.php/cogitare/article/ view/24932/18480

19. Carvalho JFS, Chaves LDP. Supervisão de enfermagem no uso de equipamento de proteção individual em um hospital geral. Cogitare Enferm [Internet]. $2010 \mathrm{Jul}-$ Set [cited 2015 Jul 8]; 15(3):513-20. Available from: http:/ / dx.doi.org/10.5380/ce.v15i3.18897

20. Uchimura KY, Bosi MLM. Abilities and skills among Family Health Strategy workers. Interface (Botucatu) [Internet]. 2012 Mar [cited 2015 July 08]; 16(40):149-60. Available from: http://dx.doi.org/10.1590/S141432832012005000006

21. Silva MVS, Silva LMS, Dourado HHM, Nascimento AAM, Moreira TMM. Limites e possibilidades da auditoria em enfermagem e seus aspectos teóricos e práticos. Rev Bras Enferm. [Internet]. 2012 Jun [cited 2015 Jul 01]; 65(3):535-8. Available from: http:// dx.doi.org/10.1590/S0034-71672012000300021

22. Pinto KA, Melo CMM. Nurses' practice in health audit. Rev Esc Enferm USP [Internet]. 2010 Sep [cited 2015 July 08]; 44(3):671-8. Available from: http:// dx.doi.org/10.1590/S0080-62342010000300017

23. Viana CD, Bragas LZT, Lazzari DD, Garcia CTF, Moura GMSS. Implantação da auditoria concorrente de enfermagem: um relato de experiência. Texto Contexto Enferm [Internet]. 2016 [cited 2016 Aug 15]; 25(1):e3250014. Available from: http://www. scielo.br/scielo.php?script=sci_arttext\&pid=S010407072016000100702\&lng=en

24. Hayashida KY, Bernardes A, Maziero VG, Gabriel CS. A tomada de decisão da equipe de enfermagem após revitalização do modelo compartilhado de gestão. Texto Contexto Enferm [Internet]. 2014 Jun [cited 2016 Aug 15]; 23(2):286-93. Available from: http://www. scielo.br/scielo.php?script=sci_arttext\&pid=S010407072014000200286\&lng=en 